and small beasts of thirty-four different varieties, according to a carefal report of Dr. Alfred Hill, published some few years ago.

The only point remaining, and worthy of further allusion, is that all the conclusions formulated by Sir Spencer Wells in 1878, based on his own experience, have, without exception, been reversed by the statistics freed from his heavy mortality. One of his conclusions was a very serious one, for it hampered progress very much, especially in operations for removal of the uterine appendages. It was to the effect that removai of two ovaries was a far more fatal operation than removal of one.

This conclusion ought to have been, that two pedicles in a clamp were far more risky than one ; now it is evident that it is in no way more risky to remove two ovaries for cystoma, or anything else, than to remove one. In connection with this point, it may be as well to say that, in the period embracing this series of 139 successful cases, there has not been in my practice a single incomplete operation.

Now that we have cleared away all our superstitions, and view the facts in a more reasonable light, we see this operation of ovariotomy not only the most successful achievement in surgery, but we have to regard it as a portal, which, opened within the last eight years, has led to innumerable other blessings to suffering bumanity.

\section{CONTAGIOUS PNEUMONIA.}

\section{By WILliaM BRUCE, M.A., M.D., Dingwall.}

THe following paper was read at a meeting of the Inverness and Ross Sub-branch of the Northern Counties Branch of the British Medical Association, and is now published as a continuation of a former contribution, on Contagious Pneumonia, which appeared in the Journal on August 11th, 1883.

It may be taken as quite settled that epidemics of pneumonia, of an infectious character, do occur at rare intervals; the evidence being complete, not only on the side of the patients' histories occurring in grouns, with definite connections locally, but also from the proof of active organisms, with well defined characters, having been found, when properly searched for and examined. I am sorry I did not possess the necessary knowledge, or physical means, of drawing and describing those organisms in the set of cases I have seen; but the fact will be noted that organisms were seen, at one stage numerous and active, and at a later stage either inactive, or not to be found at all.

There have been occasional cases of pneumonia observed since, in this district; but they have been very few (fifteen in 1884) in my practice, and do not exceed the usual number in similar localities. With regard to the natural history of contagious pneumonia, I would draw attention to the almost constant presence of pleurisy as a concomitant of pneumonia ; indeed, it was often the first and most striking syraptom. I think I have seen a run of pleurisy cases before, and may have missed the pneumonia. The interesting point is that, in cattle, a similar disease is called pleuro-pneumonia.

As to treatment, it will be noticed that one case was bled from the arm. This I have often previously done in pneumonia, and, twentyfive years ago, it was my common practice. My friend, Professor Dyce Davidson, of the University of Aberdeen, saw the case referred to, and urged me to bleed. He and others considered that the bleeding saved the patient's life. Certainly the girl was, that day, in the gravest danger, with respirations over 80 per minute and a ranning pulse. But I think the tide was turned before she was bled. Certainly the bleeding did no harm, and gave relief, as it usually does. On the whole, my experience is that venesection has no real influence on pneumonia-nor, let me add, on one or two other diseases in which, I may say, I have invariably bled patients freely from the arm, namely, puerperal and albuminuric convulsions. I am not, however, disposed to abandon the lancet, any more than many other doubtful remedies of the Pharmacopceia. I would draw the line, however, at the hither side of calomel and large doses of antimony, as I equally disapprove of brandy and beef-tea, given as a matter of routine. Poultices, continued for a reasonable time, say, two or three days, followed by firm strepping, mild expectorants, regulated nourishment, and good nursing, with plenty of fresh warm but not hot air, are, to my mind, the esentials of treatment in contagious pneumonia. The healthy and strong recover; the very old, and especially the dissipated, die off quickly. And this will continue to be the result in such patients, in spite of all treatment. I hope my neighbour, Dr. Adam, will contribate his cases and experience; and then, with Dr. Sutherland's (see Joornal, August 11th, 1883, and Collective Investigation Record, vol. ii), we shall have a pretty complete picture of the disease I have endeavoured to describe, as witnessed in Wester Ross in 1882-83. I should like to know if any of our members have any reason to believe in the occasional epidemic character of acute rheumatism. I think I could bring forward a series of cases, tending to show that acute rheumatism does, now and again, become epidemic.

Group v. CASE XVII. ${ }^{1}$-Mrs. R. was first seen on August 26 th, 1883. The day before she had felt chilly, and, in the evening had a rigor; pulse 102 , temperature $101^{\circ}$. August 27 th. Pulse 102, temperature $101.5^{\circ}$. She had a flushed face, pain in the right side, and cough. August 28 th. She had pain in the side and congh, with rusty sputum ; pulse 112 , temperature $102,4^{\circ}$, respirations 40. August 30 th. She had a troublesome cough, with tenacious rusty sputum, great thirst, and foul tongue; pulse 112 , temperature $102.5^{\circ}$, respirations 39. August 31 st. There were dulness at both bases, bronchial breathing, and rusty sputum; pulse 128 , temperature $101^{\circ}$, respirations 40. September 1st. Pulse 92, temperature $101.6^{\circ}$, respirations 52 . The other symptoms continued. The spntum was examined microscopically, and found to contain numerous micro-organisms, $1.10,000$ th to 1-14,000th part of an inch in diameter, some round, some dumb-bellshaped. September 3rd. Her condition was little altered. September 4th. Pulse 88 , temperature $101.6^{\circ}$, respirations 60 . There were dulness and bronchial breathing, with sonorous rates, all over the left and upper lobe of the right lung. Air was entering the lower lobe of the right lung fairly well. September 5th. Pulse 100, respirations 52. Both sides behind were full of moist rales. The sputum was tenacious, but not bloody. September 7 th. Pulse 100 (emptying), respirations 52 . The right lung was pretty clear. September 10th. Pulse 94, temperature 101, respirations 57 to 60 . There was cough. The pulse was fairly strong, and had not the suddenly emptying character of the few former visits. The patient could lie down in bed on the left side with comparative comfort. The sputum was muco-purulent, tenacious, and in great quantity. The right lung was clearing up well ; the breath-sounds were rough; there were no adventitious sounds. In the left lung were rales and bronchial breathing. September 13th. She was a good deal improved; pulse 90 , respirations 30 . The cough was much less troub'esome, and the lungs were clearing up well. This case progressed favourably, and the patient is now quite well.

CAse XvilI. - Mary H., aged 16, residing at Novar, Ross-shire, was admitted to the Ross Memorial Hospital, Dingwall, on September 1st, 1883, suffering from acute pneumonia. Two years ago, the patient had typhoid fever, and was then treated in this hospital for three weeks, at the end of which time she was discharged convalescent. Since that time, her health had continued good until two days before admission, when the patient was seized with her present illness. The patient had acted in the capacity of domestic servant to Case XvIr, who, on August 25th, was laid up by a very sharp attack of pneumonia. The patient continued to attend to her mistress unti August 29 th, when she herself became the subject of the same disease. On that day (29th), the patient had a rigor, and severe pain in the left side. She became very feverish and weak, and took to her bed. On the 30th, she was visited, when the following state of matters was found. She had pain in the left side. There was dulness up to within one inch of the inferior angle of the scapula behind, and to within one inch of the nipple in front. There were fine crepitation, cough, and rusty sputum. On August 31st, a small quantity of sputum, which had been collected in a stoppered bottle which had previously been thoroughly cleaned, was examined under the microsoope. Great numbers of minute organisms were discovered, moving about in the most lively fashion. September 1st. The patient was removed to hospital. The temperature stood at $101^{\circ}$, pulse 105 , respiretions 42. She had flushed face and pain in the side. Dulness of the left side was well marked up to the angle of the scapula, two inches below which fine crepitation could be heard; and, in the axillary line, a distinct pleuritic friction-sound: On the morning of September 2nd, temperature $102.8^{\circ}$, pulse 125 , respirations 46 . She was flushed, had pain in the side, "friction-sound, crepitation, and dulness ; and, on the whole, there was little change from the previous day. The evening temperature was $108^{\circ}$, pulge 130 , respirations $50 .:$ Today; the patient was made to expectorate upon a slide; which was im. mediately placed under the microscope, when numerous microorganisms were found to be present in the sputum. It moy be mentioned that, after this date, though the organisms were still present, they were never found to move about as they did in the earlier stages of the attack. September 3rd. The nurse reported that the pacient had had a very restless night. On examination of the chest, it was found that the left lung presented no change from the records of the previous day, but that the right lung had also bocome affected, being

1 The groups and crses are numbered in continuation of thos, th the former paper. 
call ap taithe level of the nipple in front, and, to the lower angle of 17penpule behtud, viels fine erepitation. There was lividity of the

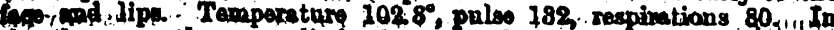
tho aftarmoon, there was littlo ohange, and tho very harried reapira. tipns were almost entimaly branchial. Blood to the extent of eight or top qunces: was taken from the arm. This was followed by murked inproremont in the pulse; the respirations foll to 52 ; and tho pationt falt much easjer, and slopt a littlo. The temperature remained at 102. 8. September 4th. The patient had restod well during the night. Temperature $28.4^{\circ}$, pulso 98 , respirations 40 . The physical sigme ro. mained the same those of the previous dey. In the evening, the pulse was 88, temperature $98,4^{\circ}$, respirations 32 . There were dulness and bronchicil breathing, with a few load rales and friction-sound on the loft side; small erepitation, with bronchial bresthing, on the right: The eputum continued rusty and tenacious. September 6th. Morning: pulse 92, temperature $98.4^{\circ}$, respirations 40 . Dulness was not diminished. Crepitatio redux was heard. Evening : pulse 88, tomperature $98.4^{\circ}$, respirations 26. September 7th. Pulse 80, rospirations 32, temperature $98.4^{\circ}$. Evening : pulse 76, temperature 98. $1^{\circ}$, respirations 32 . Septomber 8 th. Pulso 72 , respirations 28 , temperature $98.4^{\circ}$. Evening : pulse 70 , temperature $98.4^{\circ}$; respirs tions 24. September 9th. Pulse 72, tempersture 98. $4^{\circ}$, respirations 24. There was dulness to within one inch of the spine of the scepula on the left side behind, and to the nipple-line in front. Crepitatio redux was heard. The pleuritic friction-sound was disappearing. $\Delta$ ir was ontering the lung fairly well. On the right side, dulness was more marked than on the left. Breathing was bronchisl. There was increased rocal fremitus. The patient continued to do very well, and s week later was dismissed.

CABE XIX.-G. Ma.L., on Wednesday, which was a wet, stormy dey, was engaged in out-door labour. The same erening he felt unwoll ; the next morning he folt worse, but did not consider bimself anfficiently ill to stay away from his work. Accordingly ho went at the usual hour, but had to return home, feeling very cold, and com. plaining of cough, and pain in the side. That night he had a rigor. On the following Sunday he was seen, when ho was found to have a pulse of 104, temperature $103.2^{\circ}$, respirations 30 . There were dulness at the baso of the left lung, fine crepitation, and rusty sputum. This, like the two preceding, was a typical case of pnoumonia. On the ninth day, the crisis took place. The patient rapidly improved, and is now quite well.

CABE $\times x-J$. S. was exposed to the weather on same day as the last case. On that (Wednesday) evening, according to his own cocount, ho bocame rery ill, and took to his bed. On Sunday he was secn, and found to have marked symptoms of a double pnenmonis palse 104, temperature $103.4^{\circ}$, respirations 56. There was rusty sputam, with fine cropitant rales, and dulness at both bases, and severe pain in the back. The heart-sounds were irregalar, inter. mittent, and weak. Tho patient's aspoct was very dejected, and, altogether, his symptoms were such as to hold out little hope of recorery. In two days he died.

All the cases of this group occurred within a radius of a quarter of 8 mile.

GroUP VI. CASE XXI.-MoI. (child) was first visited on August 6th. There were loss of appetite, pain in the side, and flush. Pulse 160, tomperature $103^{\circ}$, respirations 52 . There was dulness at the left base, fine crepitation, and cough. Anguet 10th. The sputum was rusty There was fine crepitation at the spine of the scapula, flush, and dyepnces. August 12th. There was copious perspiration, with deferrencence. The cough was alightly abated. The pain in the side continned. Rapid recovery followed.

CABE XXIr.-J. McD., aged 8, was first visited August 10th. The patient had been ill for some days; pulse frequent, temperature $100^{\circ}$. There were signs of consolidation at the left base. August 12th. Pulse 105; temperaturo $100: 6^{\circ}$, respirations 28. There were dulness over theleft base, increased vocal fremitus, and resonance. August 16th. Pulse 120, temperature $102^{\circ}$, respirations 32. There were dulness, pain in the side, and cough with tenacions sputum. August 18th. Pulse 90, temporature 101. patient had cough, with tenscious sputum; he sweated a good deal, and was flushed. August 22nd. Pulse 100, temperature $98.4^{\circ}$, respi. rations 26 ; crepitatio redux was heard. There was dulness at the right bese. August 26th. Pulso 100, temperature $99^{\circ}$, respirations 25 ; cough was still present, but the patient was much improved.

Cass XXI11. - F., aged 50, was visited on August 16th. For a fom days previous be had felt unwell, with an occasional shivering fit. Thinking that he was suffering from an ordinary cold, he took o dose of calomel. This did not relieve him, and, on the appearance of blood in his sputum, he cent for a medical man. At the time of visit, there were cough with bloods expectoration; dulnewe and fipe cropitent w whe at the def eper; pule 65. intermittont. Auguat 18th. Therer dulness and fine crepitation at the apex of the left lung. Tho bload in tho oputum wa doninished; puloe 76. Angunt, 20th. Pulwi 100, respiration 82 ; aropitation $F a s$ heard at the left apox. Thor wa suspicion of commoneing right pneumonis Somo of the sputum in this and the provious caes was collected in stoppered bottlo and of amined, when miaro-organiams, oimilar to those eleady opoken 'of, were found. Angust 24 th. The dalness and crepitation the laft apex continued. The rest of the pulmonary apparatus was clear. Blood had ceasod to appear in the sputum; pulse 80, tomperatare 98. $4^{\circ}$, respirations 28 . The microscope was brought to the patiente house, and the sputum was exanined; micro-organisms wero found. A fow days later the sputum was again exsmined (fresh supply), bat no organisms could be found. This patient was weakly, and took : long time to recaver.

\section{A CASE OF PNEUMONIA, OCCURRING AT, A COLD HIGH ALTITUDE.}

BY A. TUCKER WISE, M.D.

C. J., aged 30, an Italian, native of a malarious district in Italy, was seized with giddiness, sickness, and shiverings, on January 20th, at 8 P. M. He was in bed, complaining of pain orer the left lumbar region. He looked pale and sleepy. Pulse 100, strong, large, and of moderate tension; temperature $101^{\circ}$, respirations 28, conjunctivæ blanched. He romited during the examination of his chest. There was no delirium nor rigors. The chest presented signs of harsh entry of air over bothsides of his back; general impaired resonance, but no absolute dulnees. With the slight cough he had, there was rusty, gluey expectoration. His urine was normsl. The bowels were open; tongue moist, not costed. He was given a hypodermic injection of morphine, and ordered liquid diet.

January 21st. He complained of pain in the left side; temperature $101^{\circ}$, respirations 28 , pnlse 100 . His lips were bright-red, and his face flushed a little. There was dulness over the left infrascepular region, limited to an ares of four square inches; fine crepitations were heard there, with bronchophony and tubular breathing. Ho was ordered a mustard-leaf over this spot, and half a drachm of compound spirit of ammonis, in water, every four hours; also 5 grains piluls hydrargyri with coloc., at night.

January 22nd. The bowels were open freely ; his face was flushed spleen eularged. On inquiry, it was found that he had suffered; a fow years ago, from malarial fever; pulso 116, temperature, 104.1 respirations 30. He hed great thirst; his tongue was white and moist Ho was ordered grain of opium, and turpentine stupes

Jannary 23rd. Respirations 30, pulse 100, tempersture 104; dul. ness and tubular bresthing extended to the right side, and over the whole of the left lung. He slept well during the previous night. was ordered to hava 5 grains of quinine.

January 24th. Respirations 32, temperature $101.7^{\circ}$, palse 100 , regular, but weak. He was ordered to have half a drachm of com. pound apirit of ammonia, and half a grain of powdered opinm, erery four hours, in water.

January 25th. Respirations 33, temperature 103.2 $2^{\circ}$, pulse 106 (dicrotus). The urine was loaded with lithates. Owing to the low tempersture of the room, his medicine was frozen in the bottle. He wes ordered to have 5 grains of quinine.

January 26th. Temperatare $100.6^{\circ}$, respirations 24, pulse 104. Ro. dux crepitations were heard over the whole of the right back. His tangue was moist, and costed with white fur. He had slept well, and coughed less. The sputum was still rusty coloured. All liquids in the room were frozen, and the vapour of his bresth was plainly perceived from the other end of the apartment. The bottle of milk, and also the medicine-bottle, he placed under his pillow, to guard againot their solidification. He had not felt the cold. His aspect was im. proved. The tempersture in the open air this day was $2^{\circ} \mathrm{Fahr}$. 9 A. U., $16^{\circ}$ Fahr. at noon.

January 27 th. Temperature $98.2^{\circ}$, respirations 22, pulse 80. There was amelior ition of all bad symptoms. The temperature of the room stood at $25^{\circ} \mathrm{Fahr}$. at the time of $\mathrm{my}$ visit.

January 28th. Temperature $97.8^{\circ}$, respirations 23, palse 64. The temperature of the bedroom was $21^{\circ}$ Fahr.

January 29 th. He was progressing favourably. The temperature of the bedroom was $23^{\circ}$ Fahr. 